AGRARIS: Journal of Agribusiness and Rural Develpoment Research

Vol. 4 No. 2 Juli-Desember 2018
Riyani $^{1 *}$, Darsono², Minar Ferichani ${ }^{2}$

1) Program Studi Magister Agribisnis, Universitas Sebelas Maret

2) Program Studi Agribisnis, Universitas Sebelas Maret

*) Email korespondensi: riyani.new@gmail.com

\section{Analisis Permintaan Ekspor Komoditas Pertanian Indonesia oleh Pasar Tiongkok}

\author{
Analysis of Export Demand for Indonesian \\ Agricultural Commodities by the Chinese Market
}

DOI: http://dx.doi.org/10.18196/agr.4267

\begin{abstract}
China is one of the main export destination of Indonesian agricultural commodities. Nevertheless, the export trend of Indonesian agricultural commodities to China during 2012 . 2016 tend to declined, therefore it is necessary to analyze it. This research aimed to analyze the determinant of Indonesian agricultural commodities export demand by China. Indonesian agricultural commodities export demand was estimated using a regression model on panel data. Panel data in this research consisted of ten data of Indonesian agricultural commodities export to China during 1999-2016 period. The results showed that Indonesian agricultural commodities export demand by China was significantly influenced by real GDP per capita of China, real exchange rate, export price of agricultural commodities and import tariff of agricultural commodities in China. An increasing in real GDP per capita lead an increase in Indonesian agricultural commodities export demand. The depreciation of Rupiah which was expected to increase export demand, but in this research it decreased Indonesian agricultural
\end{abstract}

commodities export demand from China. In addition, Indonesian agricultural commodities export demand tend to increased despite the export prices of agricultural commodities and import tariffs of agricultural commodities in China increased.

Keywords: agricultural commodities, export demand, panel data

\section{INTISARI}

Salah satu negara yang menjadi tujuan utama ekspor komoditas pertanian Indonesia adalah Tiongkok. Namun demikian, trend ekspor komoditas pertanian Indonesia ke Tiongkok selama kurun waktu tahun 2012-2016 cenderung menurun, oleh karena itu perlu dianalisis penyebabnya. Penelitian ini bertujuan untuk menganalisis faktor yang mempengaruhi permintaan ekspor komoditas pertanian Indonesia oleh Tiongkok. Model permintaan ekspor komoditas pertanian Indonesia diestimasi menggunakan regresi data panel. Data panel yang digunakan terdiri dari data sepuluh komoditas pertanian ekspor Indonesia ke Tiongkok selama kurun waktu 1999-2016. Hasil penelitian menunjukkan bahwa permintaan ekspor komoditas pertanian Indonesia oleh Tiongkok secara signifikan dipengaruhi oleh GDP riil per kapita Tiongkok, nilai tukar riil Rupiah, harga ekspor komoditas pertanian dan tarif impor komoditas pertanian di Tiongkok. Peningkatan GDP riil per kapita Tiongkok akan meningkatkan permintaan ekspor komoditas pertanian Indonesia. Depresiasi nilai Rupiah yang diharapkan dapat meningkatkan permintaan ekspor justru menurunkan permintaan ekspor komoditas pertanian Indonesia oleh Tiongkok. Selain itu, permintaan ekspor komoditas pertanian Indonesia meningkat meskipun terjadi kenaikan harga ekspor komoditas pertanian dan juga tarif impor komoditas pertanian di Tiongkok.

Kata kunci: data panel, komoditas pertanian, permintaan ekspor

\section{PENDAHULUAN}

Indonesia telah banyak terlibat dalam perdagangan internasional, baik ekspor maupun impor dengan berbagai negara di belahan dunia. Ekspor Indonesia selama kurun waktu tahun 2012 2016 cenderung mengalami penurunan. Hal ini disebabkan adanya krisis finansial pada tahun 2011 yang menyebabkan permintaan ekspor dari negara tujuan ekspor Indonesia mengalami penurunan. 
Demikian juga impor Indonesia selama kurun waktu tersebut juga cenderung mengalami penurunan.Trend penurunan ekspor tersebut, tidak hanya terjadi pada perdagangan Indonesia dengan dunia namun juga terjadi pada perdagangan bilateral Indonesia dengan Tiongkok. Tiongkok merupakan salah satu kekuatan ekonomi dunia, dan telah menjadi salah satu mitra dagang terpenting Indonesia dari tahun ke tahun (Setiawan, 2012). Selain itu, Tiongkok merupakan salah satu negara yang memiliki jumlah penduduk terbanyak di dunia dan wilayah yang luas. Hal ini menjadikan Tiongkok sebagai pasar yang potensial bagi produk-produk Indonesia, termasuk produk pertanian.

Sebagai negara mitra dagang utama Indonesia, selama kurun waktu 2013-2016, total perdagangan antara Indonesia dengan Tiongkok paling tinggi diantara negara-negara mitra dagang yang lain, namun demikian Tiongkok juga merupakan negara penyumbang defisit perdagangan terbesar bagi Indonesia. Berdasarkan data dari Kementerian Perdagangan, selama kurun waktu 2012-2016 trend ekspor ke Tiongkok menurun sebesar 8,76\% sedangkan trend pertumbuhan impor meningkat sebesar $0,8 \%$. Total nilai perdagangan pada tahun 2016 adalah sebesar US\$ 47,58 miliar, dengan ekspor Indonesia senilai US\$16,78 miliar dan impor senilai US\$ 30,80 miliar. Total nilai perdagangan tahun 2016 meningkat dibandingkan tahun sebelumnya yang hanya mencapai US $\$ 44,57$ miliar (Kementerian Perdagangan, 2017).

Selama kurun waktu 2012-2016, perdagangan antara Indonesia dan Tiongkok lebih didominasi oleh sektor non migas. Salah satu komoditas non migas yang menjadi unggulan ekspor Indonesia ke Tiongkok adalah komoditas pertanian. Perdagangan komoditas pertanian diidentifikasikan sebagai kunci penggerak pembangunan dan pertumbuhan ekonomi di negara berkembang yang ingin mengambil keuntungan dari liberalisasi perdagangan dalam era globalisasi (Verter, 2016). Tiongkok merupakan negara tujuan ekspor komoditas pertanian Indonesia kedua setelah India, dan komoditas utama yang diekspor ke Tiongkok pada tahun 2016 adalah kelapa sawit yang mencapai US\$ 2,21 milyar, karet sebesar US\$ 401,02 juta, kelapa sebesar US\$222,81 juta dan kakao sebesar US\$ 68,23 juta (Pusat Data dan Informasi Pertanian, 2017).

Selama kurun waktu tahun 2012 sampai 2016, ekspor komoditas pertanian Indonesia ke Tiongkok berfluktuasi dan cenderung mengalami penurunan, demikian juga impor komoditas pertanian dari Tiongkok ke Indonesia. Namun demikian, neraca perdagangan komoditas pertanian antara Indonesia dengan Tiongkok selama kurun waktu tahun 2012 sampai dengan 2016 selalu mengalami surplus sebagaimana terlihat pada Gambar 1 .

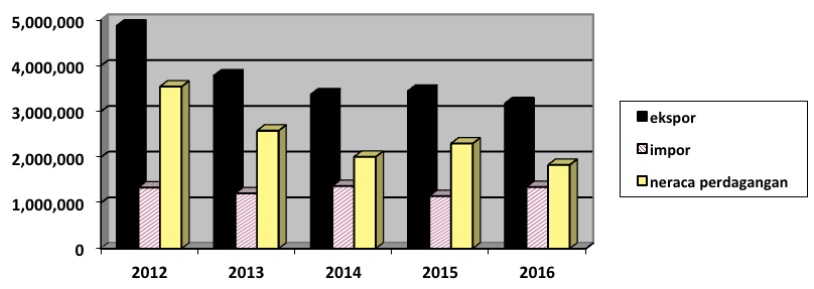

GAMBAR 1. NERACA PERDAGANGAN KOMODITAS PERTANIAN ANTARA INDONESIA AN CHINA (RIBU US\$)

Surplus perdagangan komoditas pertanian antara Indonesia dengan Tiongkok mengindikasikan bahwa perdagangan komoditas pertanian ke Tiongkok masih menguntungkan, namun demikian ekspor komoditas pertanian yang cenderung mengalami penurunan perlu mendapatkan perhatian dan perlu diidentifikasi faktor yang mempengaruhinya. Identifikasi faktor-faktor yang mempengaruhi ekspor merupakan upaya strategis guna mengevaluasi kinerja ekspor dan merumuskan upaya-upaya antisipasi (Lubis, 2010).

Beberapa faktor yang mempengaruhi ekspor antara lain volume ekspor tahun sebelumnya, jumlah penduduk, pendapatan per kapita, dan nilai tukar mata uang (Purnomowati, Darwanto, Widodo, \& Hartono, 2015). Melambatnya pertumbuhan ekonomi negara tujuan ekspor dapat menyebabkan daya beli masyarakat di negara tujuan ekspor menurun sehingga berpengaruh terhadap menurunnya permintaan ekspor suatu negara. Harga suatu komoditas juga dapat mempengaruhi permintaan ekspor. Kenaikan harga barang ekspor akan mengurangi permintaan barang ekspor tersebut di luar negeri. Apabila harga barang-barang ekspor mengalami penurunan, maka akibat yang ditimbulkan sebaliknya (Sukirno, 2001).

Faktor lain yang dapat mempengaruhi permintaan ekspor adalah nilai tukar (Purnomowati, Darwanto, Widodo, \& Hartono, 2015; Akhmadi, 2017). Nilai tukar yang berfluktuasi dan kecenderungan melemahnya nilai tukar Rupiah terhadap mata uang negara lain terutama dollar Amerika Serikat, ternyata tidak selalu mendorong peningkatan ekspor. Depresiasi nilai tukar Rupiah terhadap mata uang negara lain tersebut seharusnya 
dapat menjadikan harga komoditas ekspor Indonesia lebih murah di pasar internasional sehingga dapat mendorong peningkatan ekspor. Depresiasi nilai tukar Rupiah berpengaruh pada menurunnya ekspor produk manufaktur Indonesia (Kahfi, 2016), namun depresiasi nilai tukar dapat juga mempengaruhi permintaan ekspor secara positif (Karagoz, 2006; Khediri \& Bouazizi, 2007).

Berbagai penelitian mengenai faktor yang mempengaruhi ekspor (Akhmadi, 2017; Kahfi, 2016; Purnomowati, Darwanto, Widodo, \& Hartono, 2015; Lubis, 2010; Khediri \& Bouazizi, 2007; dan Karagoz, 2006) belum memasukkan variabel tarif sebagai salah satu faktor yang diestimasi dapat berpengaruh terhadap ekspor. Penelitian yang membahas mengenai tarif, khususnya tarif impor yang dikenakan pada komoditas pertanian yang berasal dari Indonesia oleh Tiongkok sejak tahun 1999 masih terbatas. Padahal tarif merupakan salah satu faktor yang bisa menghambat perdagangan ekspor dan impor. Pengenaan tarif akan dapat menaikkan harga barang impor sehingga permintaan ekspor dari negara lain menurun (Krugman \& Obstfeld, 1993). Hal inilah yang melatar belakangi penelitian ini untuk mengkaji tarif sebagai salah satu variabel yang diestimasi dapat berpengaruh terhadap permintaan ekspor komoditas pertanian Indonesia oleh Tiongkok. Selain itu, pada penelitian terdahulu, kajian terkait ekspor seringkali hanya fokus pada komoditas tertentu dengan tujuan ekspor ke pasar dunia. Sementara dinamika ekspor sering bersifat spesifik negara, dimana kondisi perekonomian suatu negara akan berpengaruh terhadap ekspor Indonesia ke negara tersebut, namun tidak berpengaruh terhadap ekspor Indonesia ke negara lain. Oleh karena itu perlu adanya penelitian terkait ekspor berdasarkan negara tujuan ekspor tertentu.

Berkaitan dengan hal tersebut maka tujuan penelitian ini yaitu untuk menganalisis faktor yang mempengaruhi permintaan ekspor komoditas pertanian Indonesia oleh Tiongkok. Hasil penelitian ini diharapkan dapat memberikan masukan kepada para pemangku kebijakan dalam penentuan kebijakan terkait ekspor komoditas pertanian.

\section{METODE PENELITIAN}

Data yang digunakan dalam penelitian ini adalah data sekunder yaitu data panel yang merupakan gabungan antara data deret waktu dan data antar individu. Data deret waktu yang digunakan meliputi data tahunan selama 18 tahun yaitu tahun
1999-2016. Sedangkan untuk data antar individu meliputi data 10 komoditas pertanian ekspor Indonesia ke Tiongkok. Komoditas pertanian tersebut dipilih berdasarkan nilai ekspor tertinggi pada tahun 2016 yaitu komoditas cocoa butter; technically specified natural rubber; crude coconut oil; vegetable fat and oil; coconut oil; palm oil; edible mixtures or preparations of animal or vegetable fats or oils; cocoa powder; coffee dan cotton waste. Data yang digunakan dalam penelitian ini berupa data nilai ekspor komoditas pertanian Indonesia yang diimpor oleh Tiongkok yang dinyatakan dalam US $\$$, Gross Domestic Bruto (GDP) riil per kapita Tiongkok yang dinyatakan dalam US\$, nilai tukar riil Rupiah yang dinyatakan dalam $\mathrm{Rp} / \mathrm{US} \$$, harga ekspor komoditas pertanian Indonesia yang dinyatakan dalam US\$/unit dan tarif impor komoditas pertanian Indonesia di Tiongkok yang dinyatakan dalam persen. Data pada penelitian ini diperoleh dari World Development Indicators (WDI), World Trade Organization (WTO), Trademap, dan UN Comtrade.

Untuk menganalisis permintaan ekspor komoditas pertanian Indonesia oleh Tiongkok (Xit) digunakan regresi data panel dalam bentuk model dobel logaritma dengan variabel bebas Riil Gross Domestic Product per kapita Tiongkok (RGDPCTit), nilai tukar riil Rupiah (REXRit), harga ekspor komoditas pertanian Indonesia (EXPRICEit), dan tarif impor komoditas pertanian Indonesia di Tiongkok (TarifTit). Adapun model matematisnya adalah sebagai berikut:

Ln Xit $=\alpha+\beta 1 \ln ($ RGDPCT $)$ it $+\beta 2 \ln ($ REXR $) i t+$ $\beta 3 \ln ($ EXPRICE)it $+\beta 4 \ln$ TarifTit+ uit

$\alpha$ adalah intersep; dan $\beta 1 \beta 2 \beta 3 \beta 4$ adalah parameter yang akan diestimasi

Model yang digunakan untuk mengestimasi data panel ada tiga macam, yaitu model common effect/pooled least square, fixed effect, dan random effect. Keputusan untuk memilih model yang digunakan pada analisis data panel dapat dilakukan berdasarkan pada uji Chow test, Hausman Test dan Langrange Multiplier Test (Gujarati \& Porter, 2009). Chow test atau biasa disebut dengan uji $F$ statistics merupakan pengujian statistik yang bertujuan memilih model fixed effect atau common effect. Jika 
hasil dari Chow Test signifikan menunjukkan bahwa model Fixed Effect yang digunakan. Hausman test merupakan uji untuk menentukan apakah akan menggunakan model fixed effect atau model random effect. Jika hasil dari Hausman Test signifikan menunjukkan bahwa model Fixed Effect yang digunakan. Langrange Multiplier (LM) test merupakan uji untuk menentukan apakah akan menggunakan model random effect atau common effect. Jika hasil dari LM Test signifikan menunjukkan bahwa model Random Effect yang digunakan.

Pada model REM, diasumsikan $\alpha$ i merupakan variabel random dengan mean $\alpha 0$. Sehingga intersep dapat dinyatakan sebagai $\alpha i=\alpha 0+\varepsilon i$ dengan $\varepsilon i$ merupakan error random yang mempunyai mean 0 dan varians $\sigma \varepsilon 2$, Eitersebut tidak secara langsung diobservasi ataudisebut juga variabel laten. Oleh karena itu persamaan model REM adalah sebagai berikut (Gujarati dan Porter, 2009) : yit $=\alpha 0+\beta$ 'xit + wit, $i=1,2 \ldots \ldots . n ; t=1,2, \ldots \ldots . t$

dengan wit $=\varepsilon i+$ uit. Suku error gabungan wit memuat dua komponen error yaitu $\varepsilon$ i komponen error cross-section dan uit yang merupakan kombinasi komponen error crosssection dan time series. Beberapa asumsi yang berlaku pada REM yaitu bahwa komponen error individu tidak saling berkorelasi dan tidak berautokorelasi antar unit cross-section dan time series.

Setelah dilakukan pengujian untuk memilih model yang terbaik, pada penelitian ini juga dilakukan pengujian asumsi klasik yaitu Uji Normalitas, Uji Multikolinieritas, Uji Heteroskedastisitas dan Uji Autokorelasi. Apabila model regresi data panel yang terpilih adalah model random effect, maka tidak dilakukan uji asumsi klasik heteroskedastisitas dan autokorelasi. Hal ini dikarenakan model random effect menggunakan metode estimasi Generalized Least Square (GLS), yang dipercaya dapat mengatasi adanya autokorelasi runtun waktu (time series) serta korelasi antar observasi (cross section). Metode GLS menghasilkan estimator yang dapat memenuhi sifat Best Linier Unbiased Estimation (BLUE) dan merupakan metode treatment untuk mengatasi pelanggaran asumsi heteroskedastisitas dan autokorelasi (Greene, 2007; Gujarati dan Porter, 2009).

Pengujian terhadap model yang digunakan juga dilakukan pada penelitian ini yaitu berupa pengujian koefisian determinasi (R2) untuk mengetahui besarnya proporsi pengaruh variabelvariabel bebas terhadap variabel terikat, uji $F$ untuk mengetahui apakah variabel bebas yang digunakan secara bersama-sama berpengaruh nyata terhadap variabel terikat dan Uji t untuk melihat pengaruh masing-masing variabel bebas secara terpisah terhadap variabel terikat (Gujarati \& Porter, 2009).

\section{HASIL DAN PEMBAHASAN}

Pada tahun 2016, Tiongkok merupakan negara pengimpor komoditas pertanian terbesar ketiga setelah Uni Eropa dan Amerika Serikat, yaitu sebesar $8,2 \%$ komoditas pertanian dunia. Pangsa impor komoditas pertanian Tiongkok ini mengalami peningkatan dari tahun 2000 yang hanya mencapai $2,3 \%$ (FAO, 2018). Impor komoditas pertanian Tiongkok yang mengalami peningkatan ini menggambarkan semakin tingginya permintaan ekspor komoditas pertanian oleh Tiongkok dari negara lain.

Indonesia telah mengekspor komoditas pertanian ke Tiongkok. Nilai ekspor komoditas pertanian Indonesia ke Tiongkok selama kurun waktu 1999 sampai dengan 2011 cenderung mengalami peningkatan, namun demikian selama kurun waktu 2012 sampai dengan 2016, nilai ekspor komoditas pertanian Indonesia ke Tiongkok cenderung mengalami penurunan. Ekspor komoditas pertanian Indonesia ke Tiongkok selama kurun waktu 2012 sampai dengan 2016 didominasi oleh komoditas perkebunan yang mencapai lebih dari $97 \%$ dari total ekspor komoditas pertanian Indonesia ke Tiongkok (Pusdatin, 2017).

Selama kurun waktu 1999-2016, GDP riil per kapita Tiongkok cenderung mengalami peningkatan dari tahun ke tahun (Gambar 2). Pada tahun 1999, GDP riil per kapita Tiongkok sebesar 1.646 US\$ meningkat menjadi sebesar 6894,5 US\$ pada tahun 2016. Nilai tukar riil Rupiah terhadap dollar selama kurun 1999-2015 berfluktuasi (Gambar 2), pada 
tahun 1999 nilainya sebesar Rp.14.154,18/US\$, sedangkan pada tahun 2016 nilainya menjadi Rp.10.695,21/US\$. Harga ekspor komoditas pertanian Indonesia selama kurun waktu penelitian juga mengalami fluktuasi, sedangkan tarif impor yang dikenakan untuk komoditas pertanian Indonesia di pasar Tiongkok cenderung mengalami penurunan.

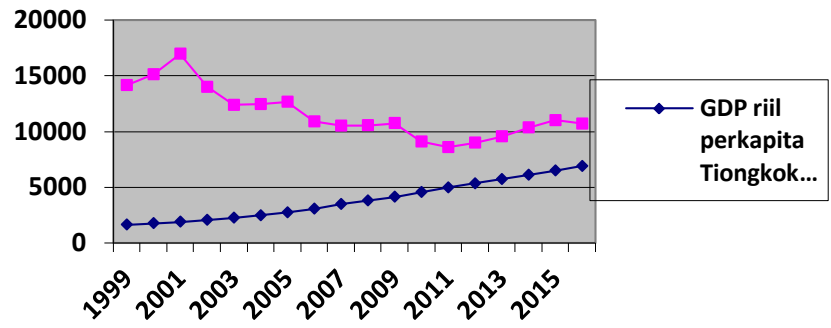

\section{GAMBAR 2. GDP RIIL PER KAPITA TIONGKOK DAN NILAI TUKAR RILL RUPIAH (1999-2016)}

Permintaan ekspor suatu negara sangat ditentukan oleh kondisi perekonomian negara pengimpor. Terkait hal tersebut, beberapa faktor yang diestimasi dapat berpengaruh terhadap permintaan ekspor komoditas pertanian Indonesia oleh Tiongkok adalah GDP riil per kapita Tiongkok, harga ekspor komoditas pertanian, nilai tukar riil Rupiah, dan tarif impor komoditas pertanian di Tiongkok. Analisis untuk mengetahui pengaruh GDP riil per kapita Tiongkok, harga ekspor komoditas pertanian, nilai tukar riil Rupiah dan tarif impor komoditas pertanian di Tiongkok terhadap permintaan ekspor komoditas pertanian Indonesia oleh Tiongkok dilakukan dengan regresi data panel.

Hasil pengujian untuk pemilihan model regresi data panel pada penelitian ini adalah sebagai berikut:

a. Uji chow

Berdasarkan hasil uji chow didapatkan nilai probabilitas cross section $\mathrm{F}$ sebesar 0,0000 lebih kecil dari 0,05 (tingkat signifikansi atau alpha), oleh karena itu dapat disimpulkan bahwa model yang terpilih adalah model fixed effect. Oleh karena model fixed effect lebih tepat untuk digunakan dibandingkan model common effect, maka selanjutnya dilakukan pengujian untuk memilih antara model fixed effect atau random effect dengan uji hausman. b. Uji Hausman

Berdasarkan uji hausman didapatkan nilai probabilitas chi-square sebesar 0,1030 lebih besar dari alpha $(0,05)$, sehingga dapat disimpulkan bahwa model yang terpilih adalah model random effect. Oleh karena model random effect lebih baik daripada model fixed effect, maka selanjutnya dilakukan pengujian untuk memilih antara model random effect atau common effect dengan uji LM test.

c. Uji LM test

Berdasarkan uji LM test didapatkan nilai probabilitas chi-square sebesar 0,0000 lebih kecil dari alpha $(0,05)$, sehingga dapat disimpulkan bahwa model yang terpilih adalah model random effect.

Model terbaik untuk penelitian permintaan ekspor komoditas pertanian Indonesia oleh Tiongkok berdasarkan pengujian pemilihan model yang telah dilakukan adalah random effect model. Oleh karena model regresi data panel yang terpilih pada penelitian adalah model random effect, maka tidak relevan untuk dilakukan uji asumsi klasik heteroskedastisitas dan autokorelasi pada penelitian ini.

Pengujian asumsi yang dilakukan pada penelitian ini hanya berupa pengujian normalitas dan multikolinearitas. Berdasarkan hasil uji normalitas didapatkan nilai probabilitas chi-square $(0,71)$ lebih besar dari $\alpha(5 \%)$, artinya sebaran data terdistribusi secara normaldan berdasarkan uji multikolinearitas didapatkan nilai koefisien korelasi antar masingmasing variabel bebas berada dibawah 0,85 , sehingga dapat disimpulkan bahwa tidak ada multikolinearitas di dalam model permintaan ekspor komoditas pertanian Indonesia oleh Tiongkok. Oleh karena itu, berdasarkan pengujian asumsi klasik yang telah dilakukan maka dapat disimpulkan bahwa asumsi klasik model regresi telah dipenuhi sehingga didapatkan persamaan regresi yang tidak bias. Hasil estimasi permintaan ekspor komoditas pertanian Indonesia oleh Tiongkok dengan menggunakan regresi data panel model random effect dapat dilihat pada Tabel 1. 


\begin{tabular}{|c|c|c|c|}
\hline Variabel & Koefisien & $\begin{array}{c}\mathrm{t}- \\
\text { Statistik }\end{array}$ & Prob. \\
\hline GDP riil per kapita Tiongkok & 2,623999 & 7,70 & $0,000^{* *}$ \\
\hline Vilai Tukar riil Rupiah & $-1,959129$ & $-2,14$ & $0,033^{* *}$ \\
\hline $\begin{array}{l}\text { Harga ekspor komoditas pertanian } \\
\text { Tarif impor komoditas pertanian di }\end{array}$ & 0,3855085 & 1,97 & $0,048^{* *}$ \\
\hline Tiongkok & $\begin{array}{l}0,598169 \\
11,60508\end{array}$ & $\begin{array}{l}1,65 \\
1,11\end{array}$ & $\begin{array}{r}0,098^{*} \\
0,266\end{array}$ \\
\hline R-square & 0,6626 & & \\
\hline F-statistik & 323,08 & & \\
\hline Prob (F-statistik) & 0.0000 & & \\
\hline Jumlah observasi & 180 & & \\
\hline
\end{tabular}

Sumber: Analisis Data Sekunder (2017)

Catatan : : signifikan pada tingkat kepercayaan $90 \%$

${ }^{* *}$ signifikan pada tingkat kepercayaan $95 \%$

Berdasarkan hasil pengujian model regresi, didapatkan koefisien determinasi (R2) sebesar 0,66, menunjukkan bahwa variasi variabel ekspor dapat dijelaskan oleh variabel GDP riil per kapita Tiongkok, nilai tukar riil Rupiah, harga ekspor komoditas pertanian Indonesia dan tarif impor komoditas pertanian di Tiongkok sebesar 66\% dan sisanya 34\% dijelaskan oleh variabel-variabel lain yang tidak dimasukkan di dalam model.

Hasil uji $F$ menunjukkan bahwa variabel bebas GDP riil per kapita Tiongkok, nilai tukar riil Rupiah, harga ekspor komoditas pertanian dan tarif impor komoditas pertanian di Tiongkok secara bersama-sama berpengaruh signifikan terhadap permintaan ekspor komoditas pertanian Indonesia oleh Tiongkok. Berdasarkan hasil uji t didapatkan variabel GDP per kapita riil per kapita Tiongkok, nilai tukar riil Rupiah dan harga ekspor komoditas pertanian signifikan pada tingkat kepercayaan 95\%, sedangkan variabel tarif impor komoditas pertanian di Tiongkok signifikan pada tingkat kepercayaan 90\%.

Hasil penelitian menunjukkan bahwa GDP riil per kapita Tiongkok berpengaruh positif terhadap permintaan ekspor komoditas pertanian Indonesia oleh Tiongkok. Peningkatan GDP riil per kapita suatu negara mencerminkan peningkatan pendapatan masyarakat di negara tersebut. Peningkatan pendapatan akan meningkatkan daya beli konsumen (Lukman, 2012), sehingga bagian yang bisa dikonsumsi atau dibelanjakan juga lebih banyak. Daya beli masyarakat Tiongkok yang meningkat menyebabkan permintaan ekspor komoditas pertanian Indonesia oleh Tiongkok juga meningkat. Selain itu, peningkatan GDP per kapita Tiongkok dapat mendorong perkembangan industri di Tiongkok, termasuk industri berbahan baku komoditas pertanian. Perkembangan industri otomotif di Tiongkok sebagai akibat dari peningkatan ekonomi negara tersebut, mendorong peningkatan ekspor karet Indonesia ke Tiongkok (Novianti \& Hendratno, 2008). Oleh karena itu perkembangan industri di Tiongkok tersebut dapat mendorong peningkatan permintaan ekspor komoditas pertanian Indonesia oleh Tiongkok. Lebih lanjut, beberapa hasil penelitian terdahulu juga menyatakan bahwa pengaruh GDP per kapita negara mitra terhadap permintaan ekspor adalah positif dan signifikan (Karagoz, 2016; Crescimanno, Galati, \& Yahiaoui, 2013; Ibrahim, 2012; Haider, Afzal, \& Riaz, 2011; Ogbonna, 2009). Hal ini menunjukkan bahwa peningkatan pendapatan negara mitra akan menyebabkan peningkatan ekspor (Akhmadi, 2017; Purnomowati, Darwanto, Widodo, \& Hartono, 2015). Namun penelitian lain menunjukkan bahwa GDP per kapita berpengaruh negatif terhadap permintaan ekspor Malaysia (Abidin, Bakar, \& Sahlan, 2013). Peningkatan pendapatan per kapita di negara mitra, menyebabkan lebih banyak barang diproduksi di negara tersebut sehingga ekspor dari negara lain berkurang.

Faktor lain yang berpengaruh signifikan terhadap permintaan ekspor komoditas pertanian Indonesia oleh Tiongkok adalah nilai tukar riil. Nilai tukar riil berpengaruh negatif terhadap permintaan ekspor komoditas pertanian Indonesia oleh Tiongkok. Secara teori, depresiasi nilai Rupiah akan menyebabkan harga ekspor lebih murah sehingga meningkatkan permintaan ekspor, namun hasil penelitian ini menunjukkan depresiasi nilai Rupiah akan menurunkan permintaan ekspor komoditas pertanian Indonesia oleh Tiongkok. Alasan yang mungkin terjadi yaitu bahwa dampak depresiasi nilai tukar Rupiah menyebabkan produk Indonesia menjadi murah bagi pembeli internasional. Oleh karena itu, pembeli menghabiskan lebih sedikit uang 
dari sebelum depresiasi meskipun mereka membeli dalam jumlah yang sama. Sebagai akibatnya, total nilai ekspor Indonesia menurun (Kahfi, 2016). Adanya penggunaan input produksi yang berasal dari impor pada produksi komoditas pertanian, misalnya pupuk. Impor pupuk Indonesia pada tahun 2016 mencapai sebesar 6,5 juta ton (BPS, 2017). Adanya depresiasi nilai Rupiah menyebabkan harga input produksi impor tersebut menjadi mahal sehingga dapat meningkatkan biaya produksi. Selain itu, adanya dampak perubahan nilai tukar terhadap inflasi misalnya kenaikan upah tenaga kerja, kenaikan harga bahan baku dan kenaikan bahan bakar minyak secara tidak langsung juga akan mempengaruhi biaya produksi. Kenaikan harga bahan bakar minyak berpengaruh pada kenaikan biaya produksi, termasuk produksi sektor pertanian yaitu pada proses produksi dan pengangkutan (Lubis, 2010). Peningkatan biaya produksi akan meningkatkan harga jual sehingga dampaknya dapat mengurangi permintaan ekspor komoditas pertanian. Adanya depresiasi nilai Rupiah akan menurunkan ekspor (Akhmadi, 2017; Lubis, 2010). Namun, nilai tukar berpengaruh positif terhadap volume ekspor Turki (Karagoz, 2016) dan juga ekspor Tunisia ke negara perdagangan utama di Eropa (Khediri\& Bouazizi, 2007). Kenaikan nilai tukar Rupiah terhadap dollar yang ditandai dengan menguatnya nilai dollar terhadap Rupiah akan mengakibatkan harga barang ekspor turun, sehingga ekspor akan meningkat (Pramana \& Meydianawathi, 2013).

Dalam transaksi perdagangan, harga suatu komoditas merupakan salah satu faktor yang harus diperhatikan karena harga dapat menjadi penentu seberapa banyak komoditas tersebut akan diperdagangkan. Pada penelitian ini didapatkan bahwa harga ekspor komoditas pertanian berpengaruh positif terhadap permintaan ekspor komoditas pertanian Indonesia oleh Tiongkok. Hal ini mengindikasikan bahwa meningkatnya harga ekspor komoditas pertanian tidak menyebabkan penurunan permintaan komoditas pertanian Indonesia oleh Tiongkok. Hasil penelitian ini berbeda dengan teori bahwa peningkatan harga ekspor akan dapat menyebabkan menurunnya permintaan ekspor komoditas tersebut. Hal ini dapat disebabkan komoditas pertanian Indonesia yang diekspor ke Tiongkok memiliki daya saing yang cukup tinggi diantaranya yaitu kakao, karet, kelapa dan kelapa sawit (Kementerian Pertanian, 2015) sehingga meskipun terjadi kenaikan harga, permintaan terhadap komoditas tersebut tidak menurun. Kenaikan harga komoditas ekspor Indonesia yang lebih rendah dibandingkan kenaikan harga komoditas yang sama dari negara lain, juga dapat mengakibatkan permintaan ekspor komoditas pertanian tersebut oleh Tiongkok meningkat karena Tiongkok lebih memilih mengimpor dari Indonesia dibandingkan dari negara lain tersebut. Selain itu, adanya perjanjian kerja ekspor dan impor mengakibatkan permintaan ekspor komoditas pertanian tetap tinggi. Perjanjian kerja ekspor-impor pada umumnya menyangkut kesepakatan harga antara eksportir dan importir serta volume permintaan dari importir (Prasetyo, Marwanti, $\&$ Darsono, 2017). Namun demikian, penelitian lain menunjukkan bahwa peningkatan harga ekspor menurunkan permintaan ekspor komoditas pertanian dan barang industri Indonesia ke sepuluh negara mitra utama (Lubis, 2010).

Faktor selanjutnya yang diestimasi dapat mempengaruhi permintaan ekspor komoditas pertanian Indonesia oleh Tiongkok adalah tarif impor komoditas pertanian di Tiongkok. Tarif merupakan kebijakan pemerintah yang paling populer untuk membatasi perdagangan internasional. Berdasarkan hasil analisis didapatkan bahwa tarif impor komoditas pertanian di Tiongkok berpengaruh positif terhadap permintaan ekspor komoditas pertanian Indonesia oleh Tiongkok. Hasil ini mengindikasikan bahwa meskipun terjadi kenaikan tarif impor, permintaan ekspor komoditas pertanian Indonesia tetap tinggi. Hal ini dapat disebabkan karena Tiongkok membutuhkan bahan pangan dan juga bahan baku untuk industri yang salah satunya berasal dari komoditas pertanian Indonesia. Di pasar Tiongkok, Indonesia menjadi salah satu negara pengekspor terbesar untuk komoditas seperti minyak sawit, minyak kelapa, produk kakao dan karet. Pangsa pasar minyak kelapa Indonesia di Tiongkok pada tahun 2016 adalah sebesar 82,7 \% sedangkan komoditas 
minyak sawit memiliki pangsa pasar 58,3 \% pada impor Tiongkok (UN Comtrade, 2017). Ekspor komoditas pertanian Indonesia ke Tiongkok sebagian besar merupakan bahan mentah atau bahan setengah jadi yang merupakan bahan baku industri di Tiongkok. Oleh karena itu, meskipun terjadi kenaikan tarif impor, permintaan ekspor komoditas pertanian Indonesia dari Tiongkok tetap tinggi karena untuk menjaga keberlangsungan proses produksi industri dalam negerinya. Meskipun terjadi kenaikan tingkat tarif, permintaan impor Malaysia tetap meningkat karena sebagian besar produk tersebut merupakan barang yang diperlukan untuk kegiatan produksi dan pengolahan (Mohamad, 2012). Hasil penelitian ini mendukung hasil penelitian yang menyatakan bahwa tarif berpengaruh signifikan terhadap ekspor lima negara ASEAN ke Korea Selatan dan Taiwan (Asirvatham, Rasiah, Thangiah, \& Naghavi, 2017).

\section{KESIMPULAN}

GDP riil per kapita Tiongkok, harga ekspor komoditas pertanian dan tarif impor komoditas pertanian di Tiongkok dapat meningkatkan permintaan ekspor komoditas pertanian Indonesia oleh Tiongkok. Namun demikian nilai tukar riil Rupiah dapat menurunkan permintaan ekspor komoditas pertanian Indonesia oleh Tiongkok. Depresiasi nilai Rupiah yang diharapkan dapat meningkatkan permintaan ekspor justru menurunkan permintaan ekspor komoditas pertanian Indonesia oleh Tiongkok. Oleh karena itu, kebijakan menjaga stabilitas nilai tukar merupakan kebijakan yang perlu dilakukan agar peningkatan ekspor Indonesia dapat terjadi.

Permintaan ekspor komoditas pertanian Indonesia tetap meningkat meskipun terjadi kenaikan harga ekspor komoditas pertanian dan tarif impor komoditas pertanian di Tiongkok. Hal ini mengindikasikan bahwa komoditas pertanian ekspor Indonesia ke Tiongkok memiliki daya saing dan dibutuhkan oleh Tiongkok untuk menjaga keberlangsungan proses industrinya. Oleh karena itu, upaya peningkatan kualitas produk perlu terus dilakukan guna tetap mempertahankan dan meningkatkan daya saing komoditas pertanian Indonesia.

\section{DAFTAR PUSTAKA}

Abidin, I. S.Z., Bakar, N.A.A., \& Sahlan, R. The Determinant of Exports between Malaysia and the OIC Member Countries: A Gravity Model Approach. Procedia Economic and Finance, 5 (2013), 12-19. https://doi.org/10.1016/\$2212 5671(13)00004-X

Akhmadi, H. (2017). Assessment the Impact of Asean Free Trade Area (AFTA) on Export of Indonesian Agricultural Commodity. AGRARIS: Journal of Agribusiness and Rural Development Research, 3(1), 9-14. https://doi.org/ 10.18196/agr.3139

Asirvatham, J., Rasiah, R., Thangiah, G., \& Naghavi, N. (2017). Impact of Foreign Direct Investment, Imports and Tariff Deregulation on Exports among Pioneering Asean Members: Panel Data Analysis. International Journal of Business and Society, 18(1), 1-12.

Badan Pusat Statistik. (2017). Impor Pupuk Menurut Negara Asal Utama, 2000-2016. https://www.bps.go.id/staticable/2014/09/08 /1044//impor-pupuk-menurut-negara-asalutama-2000-2016.html

Crescimanno, M., Galati, A., \& Yahiaoui, D. (2013). Determinants of Italian Agri-food Exports in Non-EU n Mediterranean Partner Countries: An Empirical Investigation through a Gravity Model Approach. New Medit : A Mediterranean Journal of Economics, Agriculture and Environment, 12(4), 46-54.

FAO.(2018). The State of Agricultural Commodity Markets 2018: Agricultural Trade, Climate Change and Food Security. Roma. Retrieved from www.fao.org/3/19542EN/i9542en.pdf

Gujarati, D.N., \& Porter, D.C. (2009). Basic Econometrics, 5th Edition. New York: The McGraw Hill Companies.

Greene, W.H. (2007). Econometrics Analysis, 6th Edition.New Jersey; Prentice Hall.

Haider, J., Afzal, M., \& Riaz, F. (2011). Estimation of import and export demand functions using bilateral trade data: The case of Pakistan. Business and Economic Horizons, 6(3), 4053.https://doi.org/10.1177/0015732515110 202

Ibrahim, M. A.(2012). Merchandise Export Demand function for Egypt: A Panel Data Analysis. Applied Econometrics and International 
Development,

12(1),

107-116. http://www.usc.es/economet/eaat.htm

Kahfi, A.S. (2016). Determinant of Indonesia's Export of Manufactured Products : a Panel Data Analysis. Buletin Ilmiah Litbang Perdagangan, 10(2),

$187-201$ https://dx.doi.org/10.30908/bilp.v10i2

Karagoz, K. (2016). Determining Factors of Turkey's Export Performance: An Empirical Analysis. Procedia Economics and Finance,38, 446 457.https://doi.org/10.1016/S22125671(16)30216-7

Kementerian Perdagangan. (2017). Neraca Perdagangan Indonesia dengan Republik Rakyat Tiongkok 2012-2016. Retrieved from http://www.kemendag.go.id/id/economicprofile/indonesia-export-import/balance-oftrade-with-trade-partnercountry? negara $=116$

Kementerian Pertanian. (2015). Buku Panduan Kerjasama Bilateral Bidang Pertanian Indonesia-Asia Pasifik. Jakarta.

Khediri, S., \& Bouazizi, T. (2007). An Empirical Analysis Of The Demand Elasticity For Tunisian Exports. Applied Econometrics and International Development, 7(1), 133-148. https://ideas.repec.org/a/eaa/aeinde/v7y2007i 1_11.html

Krugman, P.R., \& Obstfeld, M. (1993). Ekonomi Internasional: Teori dan Kebijakan. Jakarta : Raja Grafindo Persada.

Lubis, A.D. (2010). Analisis Faktor yang Mempengeruhi Kinerja Ekspor Indonesia. Buletin IImiah Litbang Perdagangan, 4(1), 1 13.http://dx.doi.org/10.30908/bilp.v4i1.144

Lukman. (2012). Pengaruh Harga dan Faktor Eksternal terhadap Permintaan Ekspor Kopi Indonesia. Signifikan, 1(2), 109-126. https://doi.org/10.15408/sjie.v1i2.2602

Mankiw, N.G. (2006). Pengantar Ekonomi Makro, Edisi Ketiga. Jakarta : Penerbit Salemba Empat.

Mohamad, J. (2012). The Impact of Tariff Reductions on Real Imports in Malaysia from 1980-2010. Cambridge Business \& Economics Conference. United Kingdom. http://www.gcbe.us/2012 CBEC/data/confcd/ index.htm

Novianti, T., \& Hendratno, E.H. (2008). Analisis Penawaran Ekspor Karet Alam Indonesia ke Negara Cina. Jurnal Manajemen Agribisnis, 5(1), 40-51. http://dx.doi.org/10.17358/jma.5.1.4051
Ogbonna, B.C. (2009). Export Demand Function for Nigeria: 1960 - 2005. Journal of Policy and Development Studies, 3(1) , 56-63.

Pramana, K.A.S. \& Meydianawathi, L. G. (2013) Variabel-Variabel yang Mempengaruhi Ekspor Nonmigas Indonesia ke Amerika Serikat. Jurnal Ekonomi Kuantitatif Terapan, 6 (2), 98-105.

Prasetyo, A., Marwanti, S., \& Darsono. (2017). The Influence of Exchange Rate on Indonesian CPO Export. Jurnal Ekonomi Pembangunan, 18(2), 159 174.http://doi.org/10.23917/jep.v18i2.4233

Purnomowati, H.D., Darwanto, D.H., Widodo, S., \& Hartono, S. (2015). Analisis Permintaan Karet Alam Indonesia di Pasar Internasional. AGRARIS : Journal of Agribusiness and Rural Development Research, 1(2), 136-148. https://doi.org/10.18196/agr.1217

Pusat Data dan Informasi Pertanian. (2017). Basis Data Ekspor Impor Komoditas Pertanian. Jakarta. Retrieved from http//www.database.pertanian.go.id.

Setiawan, S. (2012). ASEAN-China FTA : Dampaknya terhadap ekspor Indonesia dan China. Buletin Ilmiah Litbang Perdagangan, 6(2), 1-26. http://dx.doi.org/10.30908/bilp.v6i2.97

Sukirno, S. (2001). Pengantar Teori Makroekonomi, Edisi Kedua. Jakarta : PT. Raja Grafindo Persada.

UN Comtrade. (2017). Trade Data. Retrieved from https://comtrade.un.org/data/

Verter, N. (2016). Cocoa Export Performance in the World's Largest Producer. Bulgarian Journal of Agricultural Science, 22(5), 713-721. http://www.agrojournal.org/22/05-03.html 